\title{
SCROPHULARIACEAE DE PERNAMBUCO
}

\section{VINICIUS CASTRO SOUZA E ANA MARIA GIULIETTI}

\author{
Instituto de Biociências, Universidade de São Paulo, CP 11461 - 05499 - São \\ Paulo, SP. Bolsistas de Iniciação Científica e Pesquisa do CNPq.
}

\begin{abstract}
Scrophulariaceae of Pernambuco, northwest Brazil). The study of the family Scrophulariaceae is a part of project of "Flora of Pernambuco". In that area, the family is represented by 41 species and 16 genera: Achetaria, Agalinis, Alectra, Angelonia, Bacopa, Buchnera, Capraria, Conobea, Dizygostemon, Lindernia, Micranthemum, Monopera, Scoparia, Stemodia, Tetraulacium and Torenia. Keys to the genera and species, descriptions, illustrations and comments of the species, are presenteed.
\end{abstract}

RESUMO - (Scrophulariaceae de Pernambuco). Neste trabalho é apresentado o levantamento das espécies de Scrophulariaceae do Estado de Pernambuco. Foram encontradas 41 espécies em 16 gêneros: Achetaria, Agalinis, Alectra, Angelonia, Bacopa, Buchnera, Capraria, Conobea, Dizygostemon, Lindernia, Micranthemum, Monopera, Scoparia, Stemodia, Tetraulacium e Torenia. São apresentadas chaves para gêneros e espécies, descriçōes e ilustraçōes.

Key words: Scrophulariaceae, Pernambuco, floristics.

\section{INTRODUÇÃO}

O Estado de Pernambuco está localizado no Nordeste do Brasil, entre os paralelos de 7-10 $\mathrm{S}$ e $35-42^{\circ} \mathrm{W}$. A região compreende vários tipos de vegetação que incluem desde as dunas e manguezais litorâneos, passando pelas restingas e mata atlântica até os vários estágios das caatingas, entremeadas nos pontos mais altos pelos "brejos" (Andrade-Lima 1954). O primeiro trabalho sobre a Flora de Pernambuco, é o de Andrade-Lima (1954), onde foram descritas 258 espécies em 80 familias, incluindo materiais das zonas marítima, florestal e caatinga. Porém, as Scrophulariaceae não são mencionadas como existentes na área. A partir do final da década de 60 , começaram a ser publicados trabalhos incluindo estudos de gêneros e familias da Flora de Pernambuco (Andrade-Lima \& Lima 1968, Giulietti 1971, Andrade-Lima \& Giulietti 1972), os quais estão sendo continuados atualmente (Soares 1979, Barreto 1985, Lima 1985).

Uma familia bem representada na flora de Pernambuco pelo número de gêneros e espécies é a das Scrophulariaceae, objeto do presente trabalho o qual visa contribuir para a flora da região.

A familia Scrophulariaceae compreende cerca de 4000 espécies em 190 gêneros de distribuição cosmopolita, porém mais abundante nas regiões temperadas e montanhas tropicais (Cronquist 1981).

Schmidt (1862) referiu 36 gêneros para o Brasil, alguns dos quais hoje já pertencentes a outras familias. Desses, Angelonia, Achetaria, Tetraulacium e Herpestes, são referidos para Pernambuco, cada um deles com uma única espécie. Herpestes bacopoides Benth. coletada em Recife por Gardner, é atualmente sinonímia de Bacopa bacopoides (Benth.) Edwall.

Barroso (1952) reconheceu 32 gêneros nativos do Brasil e mais 18 subespontâneos ou cultivados. Essa autora referiu para Pernambuco, além dos gêneros citados por Schmidt (1862), Stemodia e Scoparia perfazendo um total de 10 espécies para o Estado. 
Minod (1918) ao fazer a revisão do gênero Stemodia referiu para o Estado, S. maritima L. e S. durantifolia (L.) Swartz.

Ichaso e Barroso (1970) ampliaram essa lista, com a referência de Buchnera longifolia H.B.K. para Pernambuco, sem no entanto, indicar o local de coleta.

Andrade-Lima (1966) referiu 11 espécies da familia em 8 gêneros, como "ervas daninhas" da zona da mata de Pernambuco. Esse autor citou como espécies mais freqüentes, Scoparia dulcis L. "vassourinha" e Stemodia foliosa Benth. "meladinha".

\section{MATERIAL E MÉTODOS}

Foram estudadas as coleções de Scrophulariaceae dos seguintes herbários: Departamento de Botânica da Univ. Fed. de Pernambuco (UFPe); Departamento de Botânica da Univ. São Paulo (SPF); Jardim Botânico do Rio de Janeiro (RB); Instituto de Botânica de São Paulo (SP); Instituto de Pesquisas Agropecuárias de Pernambuco (IPA); Museu Nacional do Rio de Janeiro (R); Universidade Federal Rural de Pernambuco (UFP) e Esc. Agronômica do Nordeste, Areia-PB (EAN), no Brasil. No Royal Botanic Gardens de Kew (K), foi examinada a coleção que Gardner fez no Brasil, cujas fotografias encontram-se depositadas no IPA.

Formam a base das coleções utilizadas neste trabalho, as coletas de Andrade-Lima e B. Pickel e mais recentemente, as de outros botânicos ligados ao Instituto de Pesquisas Agropecuárias de Pernambuco. Deve ser destacada também, a coleção obtida através da expedição às caatingas, financiada pela Academia Brasileira de Ciências e realizada por E. P. Heringer e D. Andrade-Lima.

A apresentação do trabalho seguiu o modelo proposto por Andrade-Lima \& Giulietti (1972). As sinonímias restrigiram-se aos basiônimos, ou nomes que apareceram como válidos em Schmidt (1862) e Barroso (1952).

\section{RESULTADOS}

\section{Descrição da familia}

Plantas herbáceas, raramente arbustivas ou arbóreas. Folhas opostas ou raramente alternas. Flores zigomorfas, raramente actinomorfas, hermafrodidas, solitárias ou reunidas em inflorescências cimosas ou racemosas; sépalas 4-5, livres ou unidas; pétalas 4-5, unidas, com tubo curto ou geralmente longo; iso a oligostêmone; ovário súpero, bilocular; óvulos muitos por lóculo. Fruto cápsula, Sementes numerosas, pequenas. Cromossomas $n=$ $6-16,18,20-26,30$ (Melchior 1964).

\section{Chave para gêneros}

1. Estames 4, raramente 5.

2. Corola actinomorfa, rotácea . . . . . . . . . . . . . . 13. Scoparia

2'. Corola zigomorfa, raramente actinomorfa, tubulosa.

3. Filetes apendiculados.

4. Pedicelo alado, flores róseas . . . . . . . . . . . . 10. Torenia

4'. Pedicelo quadrangular, flores alvas ou roxas . . . . . . . . . 11. Lindernia

3'. Filetes não apendiculados.

5. Anteras todas monotecas ................. 16. Buchnera

5'. Anteras 2 monotecas e 2 bitecas com uma das tecas atrofiadas ou anteras todas bitecas 
6. Anteras 2 monotecas e 2 bitecas com uma das tecas atrofiada . . . . . . . ........................ 6. Dizygostemon

6. Anteras todas bitecas.

7. Anteras com tecas paralelas.

8. Sépalas totalmente livres ou unidas até a.metade.

9. Sépalas iguais entre si . . . . . . . . . . . . 12. Capraria

9'. Sépalas desiguais entre si.

10. Estilete tetralado abaixo do estigma; estames $4 \ldots$. . . . :

.................. 4. Tetraulacium

10'. Estilete filiforme; estames 4-5 . . . . . 8. Bacopa

8'. Sépalas unidas além da metade.

11. Flores amarelas; estigma íntegro. . . . . . . 14. Alectra

11'. Flores alvas ou azuis, estigma bilamelado 7. Conobea

7 . Anteras com tecas divergentes ou estipitadas.

12. Anteras com tecas divergentes.

13. Cálice gamossépalo . . . . . . . 15. Agalinis

13'. Cálice dialissépalo.

14. Folhas ovais, oblongas ou lanceoladas, corola bissacada . . . . . . 1. Angelonia

14'. Folhas lineares, corola monossacada . . . ............. 2. Monopera

1'. Estames 2

15. Antera com uma das tecas atrofiada, filetes sem apêndices . . . . . . 5. Achetaria

15. Antera com as tecas com igual desenvolvimento, filetes com apêndices glandulosos na base ........................ 9. Micranthemum

\title{
DESCRIÇÃO DOS GÊNEROS E ESPÉCIES
}

\author{
1. Angelonia Humb. et Bonp.
}

Ervas eretas ou procumbentes, raramente subarbustos, Folhas opostas, alternas, ou verticiladas. Flores isoladas ou dispostas em racemos terminais; sépalas 5 , livres ou unidas próximo à base; corola bilabiada, com fauce ventricosa, a inferior apendiculada e duplamente gibosa; estames 4, inclusos, filetes curtos, anteras bitecas, lóculos divergentes; estigma capitado. Cápsula subglobosa, loculicida ou raramente indeiscente. Sementes cristado-reticuladas.

1. Folhas pecioladas.

2. Subarbustos escandentes; pedicelo com mais de $1,3 \mathrm{~cm}$ compr. . . . . . . . . . . ... . . . . . . . . . . . . . . . . . . . . . . . 1. A. hookeriana

2'. Ervas, geralmente anuais; pedicelo com menos de $1,0 \mathrm{~cm}$ compr.

3. Folhas oblongas, profundamente serreadas na porção superior e com até $1,3 \mathrm{~cm}$ larg. . . . . . . . . . . . . . . . . . . . . A. arguta

3'. Folhas ovais, não profundamente serreadas com mais de $1,5 \mathrm{~cm}$ larg . . . . . . . .............................. . . pubescens

1'. Folhas sésseis.

4. Folhas com base aguda, flores geminadas . . . . . . . . . . 7. A. biflora

4'. Folhas com base semiamplexicaule; flores solitárias. 
5. Indumento de pêlos não glandulosos . . . . . . . . . . . A. cornigera 5 . Indumento de pêlos glandulosos.

6. Filetes pilosos; brácteas cordadas na base; corola duas vezes o tamanho do cálice; cápsula subglobosa ................ A. hirta

6'. Filetes glabros; brácteas truncadas na base; corola três vezes o tamanho do cálice; cápsula oblonga .................. 4. A. gardneri

1. A. hookeriana Gardn. ex Benth. in DC. Prodr. 10. p. 251. 1845.

Figs. 1-4

Arbusto escandente, glabro. Folhas oblongas a oval-lanceoladas, $3,0-5,0 \mathrm{~cm}$ compr., 1,2-2,5 cm larg., glabras, ápice agudo, base cuneada, margem serreada a partir da metade; peciolo $0,1-0,2 \mathrm{~cm}$ compr. Flores axilares, solitárias; sépalas glabras a cilioladas; pétalas roxas, apêndice mínimo, indiviso; pedicelo $1,3-1,5 \mathrm{~cm}$ compr. Cápsula globosa a subglobosa, $0,8-1,0 \mathrm{~cm}$ compr.

Material examinado: Sertânia; margem da estrada Riacho Seco-lbimirim, Andrade-Lima 52-1024 (IPA). Arcoverde; Serra do Pinheiro, Andrade-Lima 55-2015 (IPA). Floresta; proximidades de Carnaubeira, Heringer et al. 789 (IPA, R).

O material Heringer et al. 789 , por apresentar o cálice piloso poderia ser incluido como A. hookeriana var. ciliolata (Benth.) Benth. Por outro lado, tal caracteristica aproxima mais ainda, as espécies $A$. hookeriana eA. bisaccata Benth.

\section{A. arguta Benth. in DC. Prodr. 10. p. 252. 1845.}

Figs. 5-8

Erva anual, procumbente, $20-45 \mathrm{~cm}$ alt., glanduloso-pubescente. Folhas elipticas, 2,5$3,5 \mathrm{~cm}$ compr., 1,0-1,3 cm larg., pubescentes na face superior e nas nervuras da face inferior, ápice agudo a obtuso, base cuneada, margem profundamente serreada a partir da metade; pecíolo 0,1-0,2 cm compr. Flores axilares, solitárias; sépalas subuladas com pêlos glandulosos na face dorsal; pétalas roxas, apêndice bífido com lobos agudos; pedicelo 0,5-0,7 cm compr. Cápsula globosa, $0,4-0,5 \mathrm{~cm}$ compr.

Material examinado: També, Ducke \& Andrade-Lima 43 (RB). São Lourenço da Mata, B. Pickel 113 (IPA); 2454 (IPA). Bonito; Cochos, beira da estrada, Andrade-Lima 67-4960 (IPA, SPF). Garanhuns, Andrade-Lima 67-5085 (IPA). Petrolina; perto do Rio São Francisco, Carauta 1003 (RB).

Plantas freqüentes em locais arenosos, principalmente em tabuleiros, muito embora ocorram também na zona da mata do Estado. Ocorre nos tabuleiros juntamente com Buchnera rosea porém em freqüência menor.

3. A. pubescens Benth. Comp. Bot. Mag. 2. p. 15. 1836.

Figs. $5-7$

Erva anual, decumbente, 25-50 cm alt., pubescente. Folhas ovais, 3,0-6,0 cm compr., 1,5-3,0 cm larg., face superior esparsamente pilosa, inferior pilosa nas nervuras, ápice agudo a obtuso, base truncada a cuneada, margem serreada; pecíolo 0,5-1,5 cm compr. Flores 
axilares, solitárias; sépalas pubescentes; pétalas roxo-escuras, ápêndice bicorne; pedicelo 0,5-0,7 cm compr. Cápsula globosa, 0,4-0,5 cm compr.

Material examinado: Recife; Curado, Andrade-Lima s/n (IPA). Olinda, B. Pickel 755 (IPA). São Lourenço da Mata, B. Pickel 440 (IPA); 2303 (IPA). Jaboatão; estrada da Granja Conceição, I. C. Leão 37 (IPA). Camaragibe, C. G. Leal \& Silva s/n (IPA). Igarassu; Sta. Rita, O. Tavares 813 (IPA).

Planta comum na zona da mata de Pernambuco, onde ocorre como "erva daninha".

4. A. gardneri Hook. Bot. Mag. t. 3754.1836.

Figs. 12-16

Erva anual, ereta, 50-80- cm alt., glanduloso-pilosa. Folhas lanceoladas, sésseis, 3,5$6,0 \mathrm{~cm}$ compr., 0,8-1,0 cm larg., glanduloso-pilosas, ápice agudo, base subamplexicaule, margem irregularmente serreada. Flores dispostas em racemos terminais; sépalas glanduloso-pilosas; pétalas roxo-claras, apêndice bffido com lobos arredondados; pedicelo 1,3-2,2 $\mathrm{cm}$ compr. Cápsula globosa, 0,7-0,9 cm compr.

Material examinado: Recife, Gardner 1086 (K); Curado, Andrade-Lima s/n (IPA). Gravatá, Andrade-Lima 70-5976 (IPA). São Lourenço da Mata, B. Pickel 439 (IPA); 2352 (IPA). Caruaru; Brejo dos Cavalos, Andrade-Lima 71-6492 (IPA). Entre Afrânio e Caboclo, Heringer et al. 258 (IPA, RB, R).

Planta invasora de culturas, da zona da mata de Pernambuco.

5. A hirta Cham. Linnaea 8. p. 27. 1833.

Figs. 17-19

Nome vulgar: "orelha de mocó"

Erva anual, ereta, 50-90 cm alt., glanduloso-pilosa. Folhas lanceoladas a cordiformes no ápice dos ramos, sésseis, 5,0-6,5 cm compr., 0,9-1,1 cm larg., glanduloso-pilosas, ápice agudo, base amplexicaule, margem irregularmente serreada. Flores dispostas em racemos terminais; sépalas glanduloso-pilosas; pétalas roxas com base alva e pontuações roxo-escuras, apêndice bffido com lobos obtusos; pedicelo 1,0-1,6 cm compr. Cápsula globosa, 0,5$0,8 \mathrm{~cm}$ compr.

Material examinado: Olinda, B. Pickel 55 (IPA). Rio Formoso, J. I. A. Falcão, W. A. Egler, Pereira 866 (IPA, RB). Gravatá, C. Porto 942 (IPA). Escada; Usina União Indústria, O. C. Lira 68-196 (IPA). Bom Conselho; Fazenda Arabari, E. Tenório 66-51 (IPA). Triunfo; arredores da cidade, G. Mariz 417 (IPA). Belém de São Francisco; llha do Meio, E. Tenório 67-339 (IPA).

Planta comum na zona da mata, embora seja encontrada até ao oeste do Estado. É a espécie mais freqüente do gênero em Pernambuco.

6. A. cornigera Hook. Bot. Mag. t. 3848.1836.

Figs. 20-21 


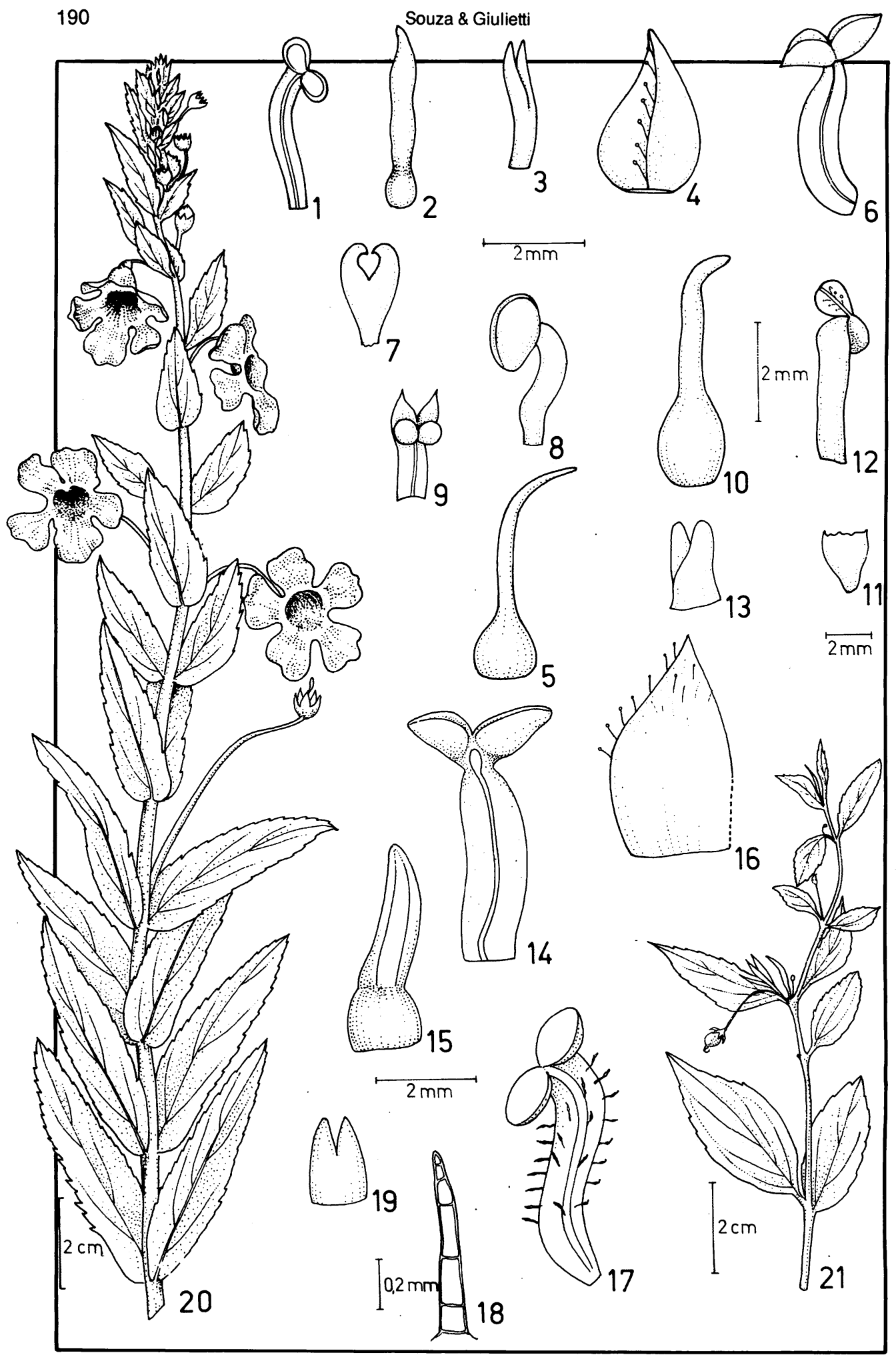


Erva procumbente, $20-50 \mathrm{~cm}$ alt., tomentosa. Folhas lanceoladas a oval-lanceoladas, sésseis, 3,0-4,5 cm compr., 1,0-1,5 cm larg., tomentosas, ápice agudo, base cuneada a subamplexicaule, margem inteira a serreada a partir da metade. Flores dispostas em racemos terminais ou axilares solitárias; sépalas subuladas, pilosas na face dorsal; pétalas roxas, apêndice bffido com lobos agudos; pedicelo 1,0-1,5 cm compr. Cápsula elipsóide, 1,0-1,3 cm compr.

Material examinado: Sertânia; Estrada Cruzeiro do Nordeste-lbimirim, Andrade-Lima 52-1023 (IPA). Petrolândia; Barreiras, Andrade-Lima 54-1973 (IPA, SPF). Entre Serra TaIhada e Petrolina, Heringer et al. 28 (IPA). Petrolina; arredores da cidade, Heringer et al. 112 (IPA). Santa Maria da Boa Vista, Heringer et al. 370 (IPA). Ibimirim, M. Ataide et al. 14 (IPA). Parnamirim, F. Araújo 108 (IPA).

A ocorrência desta planta está restrita à caatinga, na época chuvosa.

\section{A. biflora Benth. in DC. Prodr. 10. p. 254. 1846.}

Erva anual, ereta, 40-50 cm alt., glanduloso-pilosa. Folhas lanceoladas, sésseis, 3,5-6,0 cm compr., 0,5-1,0 cm larg., glanduloso-pilosas, ápice agudo a acuminado, base subamplexicaule, margem inteira a serreada a partir da medade. Flores dispostas em racemos terminais; sépalas glanduloso-pilosas; pétalas roxas, apêndice bffido; pedicelo $1,0-1,5 \mathrm{~cm}$ compr. Cápsula globosa, 0,7-0,8 cm compr.

Material examinado: Entre Barra Bonita e Petrolina, A. Castellanos 25381 (RB).

A ocorrência desta espécie está restrita aos lugares mais úmidos da caatinga, na época chuvosa.

\section{Monopera Barringer}

1. M. micrantha (Benth.) Barringer Brittonia 35 (2). p. 112.1983.

Angelonia micrantha Benth. in DC. Prodr. 10. p. 252. 1846.

Erva anual, ereta, $10-20 \mathrm{~cm}$ compr., glabra. Folhas lineares, sésseis, $1,0-1,8 \mathrm{~cm}$ compr., ca. 0,1 cm larg., glabras, ápice e base agudos, margem inteira. Flores axilares, solitárias; sépalas glabras a glanduloso-pubescentes; corola unissacada; pétalas roxas, apêndice linear, pedicelo 0,2-0,4 cm compr. Cápsula globosa, 0,3-0,4 cm compr.

Material examinado: Entre Afrânio e Caboclo, Heringer et al. 250-A (IPA, R). Parnamirim; Fazenda Travessia, F. Araújo 122 (IPA).

Este gênero foi desmembrado de Angelonia por Barringer (1983), especialmente devido à morfologia da corola.

rigs. 1-21 - Angelonia. 1-4 - A. arguta Benth. 1 - Estame, 2 - Gineceu, 3 - Apêndice da pétala, 4-Sépala. 5-7 - A. pubescens Benth. 5 - Gineceu, 6-Estame, 7 - Apêndice da pétala. 8-9-A. cornigera Hook. 8 - Estame, 9 - Apêndice da pétala. 10-12, 21 - A. hookeriana Gardn. 10 - Gineceu, 11 - Apêndice da pétala, 12Estame, 21 - Hábito. 13-16, 20-A. gardneri Hook. 13-Apêndice de pétala, 14 - Estame, 15 - Gineceu, 16 Lobo do cálice, 20 - Hábito. 17-19 - A. hirta Cahm. 17 - Estame, 18 - Tricoma do filete, 19-Apêndice da pétala.

Figs. 1-21 - Angelonia. 1-4 - A. arguta Benth. 1 - Stamen, 2 - Gynoecium, 3 - Appendage of petal, 4-Sepal. 5-7 - A. pubescens Benth. 5 - Gynoecium, 6-Stamen, 7 - Appendage of petal. 8-9 - A. cornigera Hook. 8 - Stamen, 9 - Appendage of petal. 10-12, 21 - A. hookeriana Gardn. 10 - Gynoecium, 11 - Appendage of petal, 12 - Stamen, 21 - Habit. 13-16, 20 - A. gardneri Hook. 13 - Appendage of petal, 14 - Stamen, 15 Gynoecium, 16 - Calix lobe, 20 - Habit. 17-19-A. hirta cham. 17 - Stamen, 18 - Filament hair, 19-Appendage of petal. 


\section{Stemodia L.}

Ervas ou subarbustos, geralmente glanduloso-pilosos. Folhas opostas a verticiladas. Flores solitárias ou dispostas em espigas ou tirsos dicasiais. Cálice 5-partido, segmentos quase iguais; corola bilabiada, lábio superior emarginado, inferior trilobado; estames 4, didfnamos, inclusos; anteras com tecas estipitadas; estilete filiforme; estigma inteiro ou bilobado. Cápsula septicida ou loculicida. Sementes longitudinalmente sulcadas, reticuladas ou granuladas.

1. Corola pilosa internamente.

2. Folhas de margens lisas, flores em grupos de 3 ou mais . . . . . . 5. S. heterophylla

$2^{\prime}$. Folhas de margens serreadas, flores solitárias ou geminadas.

3. Flores até $0,3 \mathrm{~cm}$ compr.; folhas até $1,0 \mathrm{~cm}$ compr. . . . . . . 2. S. verticillata

3'. Flores com mais de $0,3 \mathrm{~cm}$ compr.; folhas com mais de $1,0 \mathrm{~cm}$ compr. . . . . . .

1'. Corola glabra internamente.

4. Estipite das tecas da antera com mais de $0,3 \mathrm{~cm}$ compr. . . . . 3. S. maritima

4'. Estipite das tecas da antera com menos de $0,3 \mathrm{~cm}$ compr. . . 4. S. durantifolia

1. S. foliosa Benth. Journ. Bot. 2. p. 46.1840.

Fig. 22

Nome vulgar: "meladinha"

Erva ereta, $20-40 \mathrm{~cm}$ alt., vilosa. Folhas verticiladas, oval-lanceoladas, $1,5-4,5 \mathrm{~cm}$ compr., 0,8-1,5 cm larg., vilosas, ápice agudo a obtuso, base cuneada, margem serreada; peciolo 0,1-0,3 cm compr. Fascículos axilares com 2-3 flores; sépalas vilosas; pétalas azuis ou lilases; estigma capitado; pedicelo 0,2-0,5 cm compr. Cápsula ovóide.

Material examinado: Recife; Parque do IPA, V. Sobrinho 39 (IPA); Curado, AndradeLima s/n (IPA). Olinda, B. Pickel 442 (IPA), C. Leal s/n (IPA). São Lourenço da Mata; Tapera, B. Pickel 927 (IPA). Cabo, Andrade-Lima \& J. T. M. Costa 162 (IPA). Caruaru, AndradeLima 71-6716 (IPA). Petrolina, G. Fotius 3251 (IPA). Correntes, V. C. Lima 11 (IPA). Triunfo, V. C. Lima \& F. Galindo 181 (IPA).

Ocorre principalmente na zona da mata, como ruderal ou invasora de culturas.

2. S. verticillata (Mill.) Bondingh Zarfl. Land-bouwstr. Java. p. 165. 1916.

Figs. 23-24

Erva reptante, 8-10 cm alt., vilosa. Folhas verticiladas, ovais, 1,0-2,0 cm compr., 0,6-1,3 cm larg., esparsamente vilosas, ápice agudo a obtuso, base cuneada decurrente no peciolo, margem serreada; pecíolo $0,4-0,8 \mathrm{~cm}$ compr. Flores axilares, solitárias ou geminadas; sépalas vilosas; pétalas róseas; estigma dilatado; pedicelo $0,2-0,5 \mathrm{~cm}$ compr. Cápsula globosa.

Material examinado: Recife; Bonji, Parque do IPA, V. Sobrinho s/n (IPA); Giulietti 864 (IPA).

Espécie muito rara na região, cujo aspecto vegetativo é bastante semelhante ao de Glinus radiatus (Ruiz et Pav.) Rohrb. - Aizoaceae. Pode, no entanto, ser reconhecida pela menor intensidade da sua pilosidade. 
3. S. maritima L. Syst. Ed. 10. p. 1118. 1759.

Fig. 25

Erva decumbente, $15-30 \mathrm{~cm}$ alt., vilosa. Folhas verticiladas, lanceoladas, sésseis, 3,0-3,5 cm compr., 0,6-1,0 cm larg., glanduloso-pilosas, ápice obtuso a agudo, base amplexicaule, margem irregularmente serreada. Flores axilares, solitárias; sépalas pilosas; pétalas azuis; estilete achatado, alargando-se em direção ao ápice; pedicelo 0,4-0,6 mm compr. Cápsula ovóide.

Material examinado: Olinda, B. Pickel 635 (IPA); C. Leal s/n (IPA). Pesqueira, V. C. Lima e F. Galindo 148 (IPA). Petrolina, G. Fotius 3289 (IPA). Entre Afrânio e Caboclo, $\mathrm{He}$ ringer et al. 277 (IPA).

Esta espécie é muito distinta das outras do gênero, especialmente pelos longos estipites da antera. Foi referida por Minod (1918) para Pernambuco, com base no material coletado por Casareto 2309.

4. S. durantifolia (L.) Swartz Obs. Bot. p. 240.1791.

Capraria durantifolia L. Syst. Nat. ed. 10 p. 1116.1758.

Fig. 26

Erva ereta, 40-70 cm alt., viscoso-pubescente. Folhas opostas ou verticiladas, lanceoladas, sésseis, 3,0-4,5 cm compr., 0,4-0,8 cm larg., glanduloso-pilosas, ápice agudo, base amplexicaule auriculada, margem serreada. Flores axilares, geminadas; sépalas pilosas; pétalas violáceas; estilete achatado, alargando-se em direção ao ápice; pedicelo 0,5-0,7 mm. compr. Cápsula ovóide.

Material examinado: Recife; Curado, Andrade-Lima s/n (IPA). Olinda, B. Pickel 447 (IPA). São Lourenço da Mata; Tapera, B. Pickel 893 (IPA); 2784 (IPA); 3223 (IPA).

Esta espécie foi referida por Minod (1918) para Pernambuco, com base no material coletado por Gardner 1092.

5. S. heterophylla Giul. \& Souza Bolm Botânica 12: 1990.

Fig. $27-28$

Erva aquática, anual, $15-35 \mathrm{~cm}$ alt., glabra. Folhas decussadas, concentradas no ápice dos ramos, elipticas a ovais, sésseis, 3,1-5,1 cm compr., 1,8-3,2 cm larg., glabras, ápice obtuso a arredondado, base cuneada, margem inteira; venação acródoma, basal, perfeita. Flores dispostas em tirsos com brácteas foliáceas, lanceoladas a oblanceoladas; inflorescências parciais dicasiais, ocorrendo freqüentemente a substituição de uma das flores por ramos de $2^{\mathrm{a}}$ ou até $3^{\mathrm{a}}$ ordem; sépalas intemamente híspidas na base; pétalas lilases ou roxo-claras; pedúnculo limitado pela bractéola, 1,7-3,6 cm compr. Cápsula globosa. Sementes envolvidas, ao menos parcialmente, pela placenta.

Material examinado: Entre Serra Talhada e Salgueiro, Heringer et al. 675 (IPA, RB, SPF). Petrolina; $11 \mathrm{~km}$ sul do CPATSA, G. Fotius 3366 (IPA, PETRO, SPF); Andrade-Lima 74-7644 (IPA, SPF). Entre Petrolina e Remanso, Heringer et al. 360 (IPA, SPF).

A espécie habita lagoas temporárias na região das caatingas (Giulietti \& Souza 1990). 


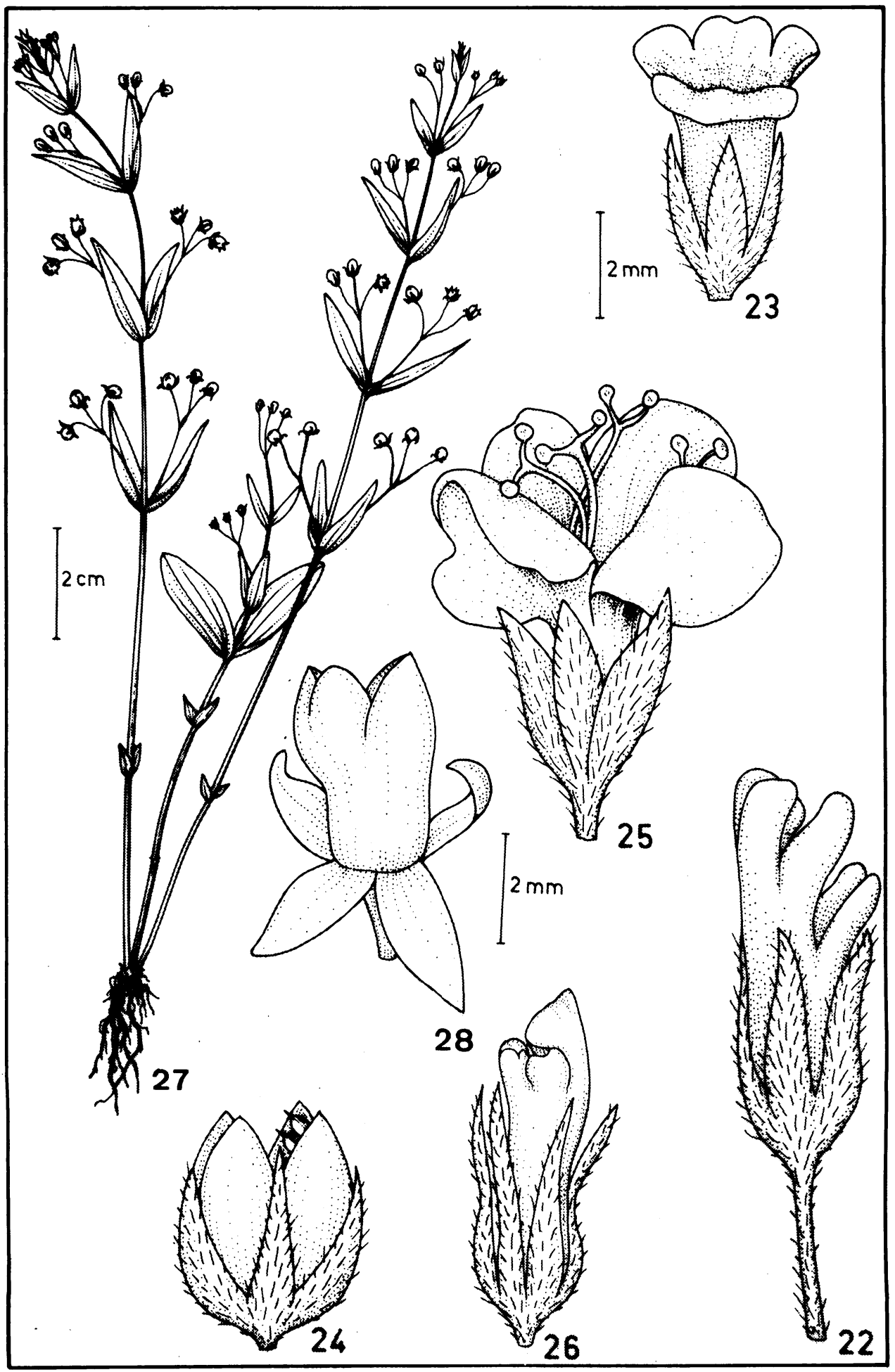




\section{Tetraulacium Turcz.}

1. T. veronicaeforme Turcz. Bull. Soc. Nat. Mosc. 16. p. 53. 1843.

Erva anual, prostrada, pilosa. Folhas opostas ou verticiladas, oval-lanceoladas, 3,0-5,0 cm compr., 1,5-2,5 cm larg., hirsuto-glandulosas, ápice agudo, base cuneada, margem irregularmente serreada. Flores axilares, sépalas livres, de tamanhos diferentes, hispidas; corola bilabiada, roxo-clara; estames 4, didinamos, filetes filiformes, anteras com lóculos paralelos; estilete tetralado, estigma bilamelado; pedicelo $0,7-1,5 \mathrm{~cm}$ compr. Cápsula subglobosa, 0,5-0,6 cm compr. com cálice acrescente.

Material examinado: Recife, Gardner 1099 (K); Curado, Andrade-Lima s/n (IPA); Areias, B. Pickel 3611 (IPA). Olinda; Rio Doce, C. Leal \& O. Alves 44 (IPA); B. Pickel 754 (IPA). Goiana, P. Mello s/n (IPA). Parnamirim, F. Araújo 141 (IPA).

As plantas desta espécie habitam de preferência locais arenosos, onde ocorrem como invasoras de culturas.

\section{Achetaria Cham. et Schlecht.}

Ervas eretas, pilosas. Folhas opostas. Flores axilares, solitárias ou dispostas em espigas terminais; cálice 5-partido, com um dos lacínios bem maior que os demais; corola bilabiada, com lábio superior indiviso ou emarginado e inferior trilobado; estaminódios 2, pequenos. Cápsula septicida, sementes reticuladas.

1. Flores em espigas .................. . A. ocymoides

1'. Flores solitárias.

2. Erva decumbente com pélos unicelulares; cápsula com valvas íntegras; folha com ápice obtuso, peciolo canaliculado . . . . . . . . 2. A. scutellarioides

2'. Erva ereta com pêlos multicelulares; cápsula com valvas bifidas; folha com ápice agudo, peciolo plano ..................... erecta

1. A. ocymoides (Cham. et Schlecht.) Wettst. Die Natürlichen Pflanzenfamilien 4 (3) p. 74. 1895.

Beyrichia ocymoides Cham. et Schlecht. Linnaea 3. p. 21. 1828.

Fig. 29

Erva ereta, 20-60 cm alt., pubescente. Folhas ovais, 2,0-4,0 cm compr., 1,0-1,7 cm larg., pubescentes na face superior, pontuadas na face inferior, ápice obtuso, base cuneada decurrente no peciolo, margem crenada; peciolo 0,2-0,3 cm compr. Espigas congestas; sépalas pubérulas, maior oval, menores linear-lanceoladas; pétalas roxas, pubérulas; estigma dilatado. Cápsula subglobosa, valvas integras.

Material examinado: Jaboatão; Prazeres, B. Pickel 3344 (IPA).

Esta espécie ocorre em locais úmidos da restinga.

Figs. 22-28 - Stemodia. 22 - S. foliosa Benth. - Flor. 23-24 - S. verticillata (Mill.) Boldingh. 23-Flor, 24Fruto com cálice persistente. $25-S$. maritima L. - Flor. 26-S. durantifolia L. - Flor. 27-28 - S. heterophylla Giul. \& Souza. 27 - Hábito, 28 - Flor.

Figs. 22-28 - Stemodia. 22 - S. foliosa benth. - Flower. 23-24-S. verticillata (Mill.) Boldingh. 23 - Flower, 24 - Fruit with persistent calyx. $25-S$. maritima L. - Flower. $26-S$. durantifolia L. Flower. 27-28-S. heterophylla Giul. \& Souza. 27 - Habit., 28 - Flower. 
2. A. scutellarioides (Benth.) Wettst. Die Natürlichen Pflanzenfamilien 4 (3) p. 74. 1895. Beyrichia scutellarioides Benth. in DC. Prodr. 10. p. 378. 1845.

Erva decumbente, ramosa, pubescente, pêlos unicelulares. Folhas ovais, subsésseis, 0,4-0,6 cm compr., 0,3-0,4 cm larg., pubérulas, ápice obtuso, base cuneada, margem revoluta, irregularmente crenada. Flores axilares, solitárias, sésseis; bractéolas ovais; sépalas glabras a pubérulas, maior oblongo-espatulada, menores linear-subuladas; pétalas roxas, pubérulas; estigma dilatado. Cápsula subglobosa, valvas integras.

Material examinado: Pernambuco, Gardner 1098 (K). Caruaru; Brejo dos Cavalos, Andrade-Lima s/n (IPA).

3. A. erecta (Spr.). Wettst. Die Natürlichen Pflanzenfamilien 4 (3) p. 74. 1895.

Beyrichia villosa Benth. in DC. Prodr. 10. p. 378. 1845.

Herpestes erecta Spr. Syst. 2. p. 801. 1818.

Fig. 30-32

Erva ou subarbusto, ereto, $40-70 \mathrm{~cm}$ alt., viloso, pêlos multicelulares. Folhas ovais, 0,8-1,2 cm compr., 0,5-0,8 cm larg., vilosas, ápice obtuso, base arredondada, margem inteira a crenada, revoluta; pecíolo 0,1-0,2 cm compr. Flores axilares, solitárias, sésseis; bractéolas estipitadas; sépalas vilosas, maior oval, menores filiformes; pétalas roxas, pubescentes; estigma dilatado, bilamelado. Cápsula subglobosa, valvas bffidas.

Material examinado: Ipojuca; Camela, Giulietti s/n (IPA). São Lourenço da Mata, $B$. Pickel 930 (IPA); B. Pickel 2418 (IPA). Caruaru, Andrade-Lima 71-6488 (IPA).

A espécie ocorre em locais úmidos ou margens de riachos.

\section{Dizygostemon (Benth.) Radlk.}

1. D. angustifolium Giul. Anais XXIII Cong. Nac. Bot. p. 77-78. 1972.

Figs. 33-34

Erva ereta, 5-20 cm alt., com pilosidade acinzentada. Folhas opostas, esparsas, curto-pecioladas, lineares, $0,5-1,0 \mathrm{~cm}$ compr., 0,8-1,3 $\mathrm{mm}$ larg., esparsamente pubescentes, ápice agudo, base cuneada, margem revoluta. Flores axilares, curto-pediceladas; bráctea lanceolada, obtusa, 2,5-3,0 mm compr., 0,7-1,0 mm larg.; cálice pentâmero, 3,0-3,5 mm compr., pubérulo, sépala posterior maior que as demais; corola violácea, $0,4-0,5 \mathrm{~cm}$ compr.; estames 4, sendo 2 com anteras monotecas e 2 com anteras bitecas com uma das tecas atrofiadas; estilete filiforme, estigma dilatado.

Material examinado: Entre Afrânio e Caboclo, Heringer et al. 251 (IPA). Parnamirim, $F$. Araújo 105 (IPA). Petrolina, G. Fotius 3880 (IPA).

Segundo Wettstein (1895), o gênero Dizygostemon (Benth.) Radlk., possui apenas a

Figs. 29-32 - Achetaria. 29 - A. ocimoides (Cham. \& Schlecht.) Wettst. - Hábito. 30-32 - A. erecta (Spr.) Wettst. 30 - Hábito, 31 - Estame, 32 - Valva de cápsula. 33-34-Dizygostemon angustifolium Giul. 33 - Flor com Brácteas, 34 - Brácteas, cálice e gineceu. 35 - Conobea scoparioides Benth. - Hábito.

Figs. 29-32 - Achetaria. 29 - A. ocimoides (Cham. \& Shclecht.) Wettst. - Habit. 30-32 - A. erecta (Spr.) Wettst. 30 - Habit, 31 - Stamen, 32 - Capsule valve. 33-34-Dizygostemon angustifolium Giul. 33 -Flower with bracts, 34 - Bracts, calyx and gunoecium. 35 - Conobea scoparioides Benth. - Habit. 


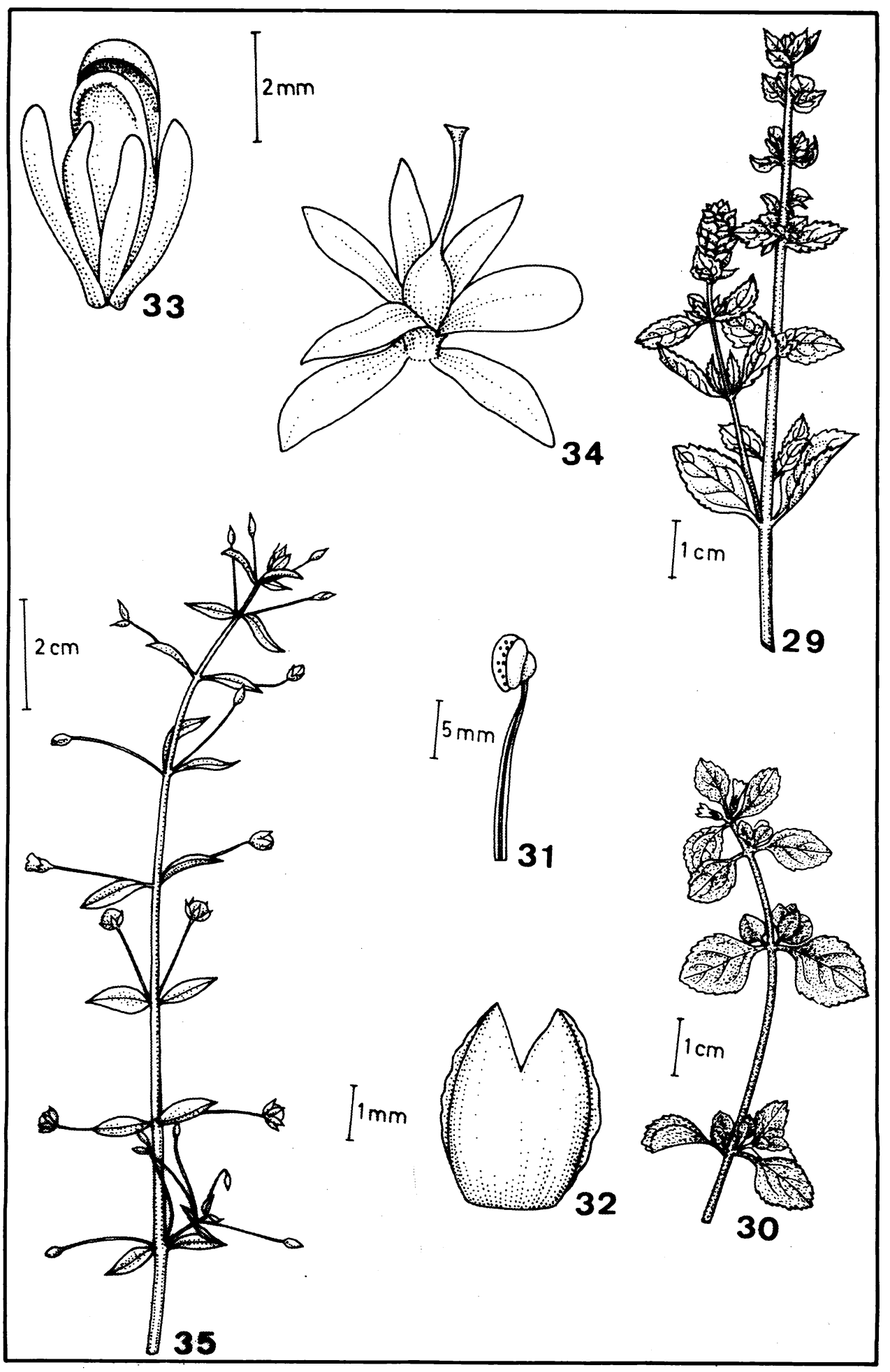


espécie D. floribundum (Benth.) Radlk. Giulietti (1972) descreveu $D$. angustifolium, que ocorre em lagoas temporárias na região das caatingas, comparando-a com a espécie anteriormente referida para o gênero (Giulietti \& Wanderley 1972).

\section{Conobea Aubl.}

1. C. scoparioides Benth. in DC. Prodr. 10. p. 391.1845.

Fig. 35

Erva de ramos estriados, glabra ou pubescente. Folhas opostas, lanceoladas, $2,0-4,0$ cm compr., 0,4-1,0 cm larg., glabras, pontuadas, ápice agudo, base atenuada, margem serreada. Flores axiliares, solitárias, bibracteoladas; sépalas 5, unidas na base, ciliadas; corola bilabiada, lábio superior bilobado, inferior trilobado; estames 4, didinamos, anteras paralelas; estigma bilamelado. Cápsula globosa, com cálice persistente.

Material examinado: Pombos, B. Pickel 2875 (IPA).

Esta espécie ocorre em locais paludosos e pantanosos.

\section{Bacopa Aubl.}

Ervas eretas ou reptantes, geralmente paludosas. Folhas opostas. Flores axilares; cálice 5-partido, segmentos desiguais; corola bilabiada 4-5-laciniada, estames 2-5, geralmente 4, didfnamos, anteras com tecas paralelas. Cápsula septicida ou loculicida; sementes reticuladas.

O gênero Bacopa Aubl. foi revalidado por Pennell (1946), tendo sido incluído Herpestes Gaertn. na sinonimia.

1. Uma a duas flores por axila

2. Estames $5 \ldots \ldots \ldots \ldots \ldots \ldots \ldots \ldots$. . . . . aquatica

2'. Estames 4.

3. Pedicelo com menos de $1,0 \mathrm{~cm}$ compr.

4. Flores alvas.

5. Estilete inteiro . . . . . . . . . . . . . . B. sessiliflora

5'. Estilete bipartido . . . . . . . . . . . . . . 9. B cyclophylla

4'. Flores azuis, róseas ou violetas.

6. Pedicelo até $2,0 \mathrm{~mm}$ compr . . . . . . . . . 7. B. gratioloides

6'. Pedicelo com mais de $2,0 \mathrm{~mm}$ compr.

7. Sépalas externas obtusas . . . . . . . . 4. B. bacopoides

7. Sépalas externas agudas ............ . B. depressa

Figs. 36-49 - Bacopa. 36-38 - B. sessiliflora Benth. 36. - Hábito, 37 - Cálice, 38 - Fruto. 39-40 - B. aquatica Aubl. 39 - Brácteas, sépalas e gineceu, 40 - Corola e androceu. 41 - B. monnieri L. - Hábito. 42 - B. salzmanii Benth. - Uma das sépalas exteriores. 43 -B. stricta (Schrad.) Edwali - Cálice, mostrando as sépalas desiguais. 44-45 - B. cyclophylla Fernald. 44 - Hábito, 45 - Flor. 46-49 - B. monierioides (Cham.) Robinson. 46 - Hábito, 47 - Gineceu, 48 - Cálice, 49 -Fruto.

Figs. 36-39 - Bacopa. 36-38 - B. sessiflora Benth. 36 - Habit, 37 - Calyx, 38 - Fruit. 39-40 - B. aquatica Aubl. 39 - Bracts, sepals and gynoecium, 40 - Corola and androecium. 41 - B. monnieri L. - Habit. 42 - B Salzmanii Benth. - External sepal. 43 -B. stricta (Schrad.) Edwall. - Calyx, showing unequal sepal. 44-45 - B. cyclophylla Fernald. 44 - Habit, 45 - Flower. 46-49 - B. monnierioides (Cham.) Robinson, 46 - Habit, 47

-Gynoecium, 48 - Calyx, 49 - Fruit. 


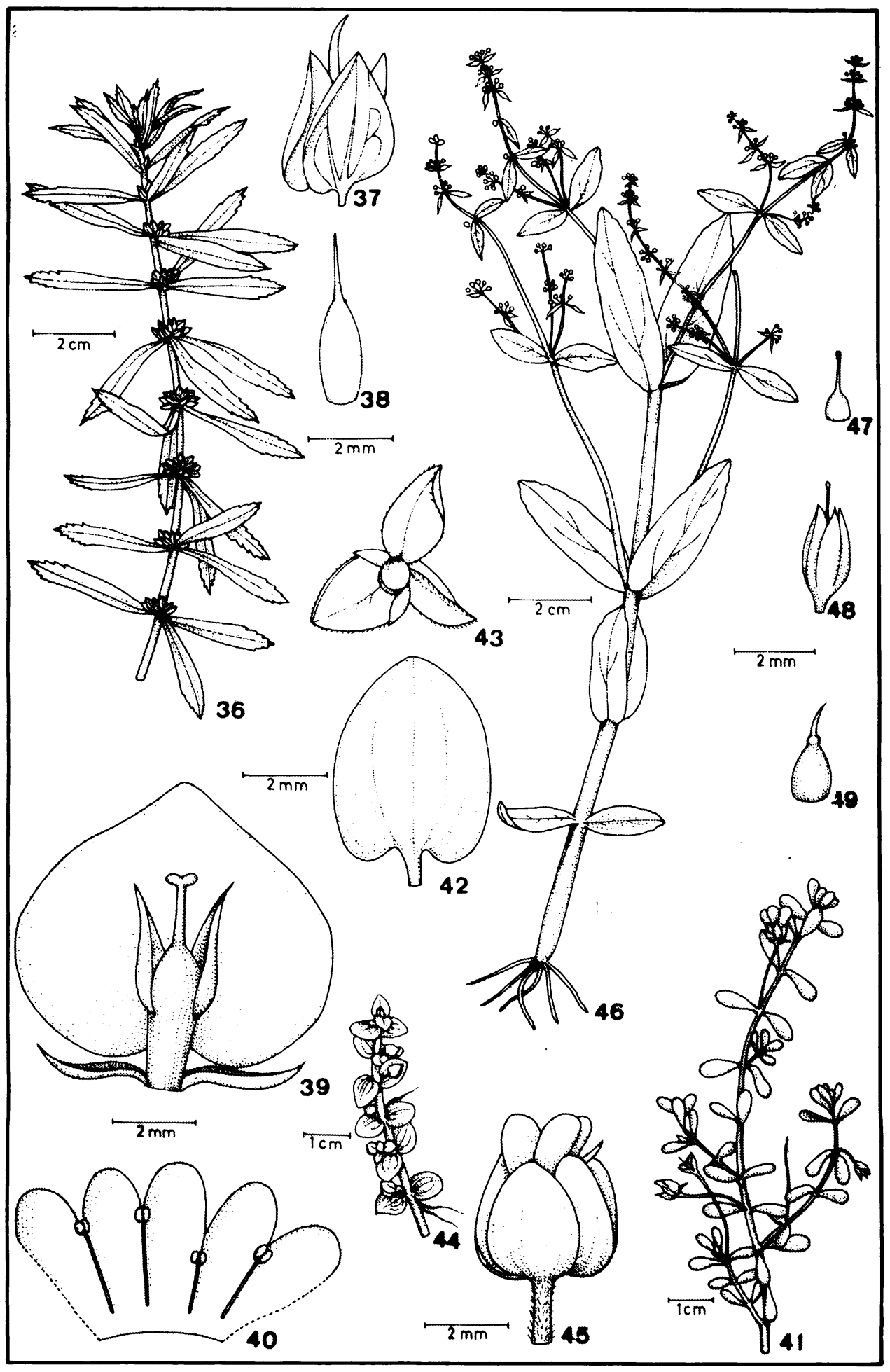


3'. Pedicelo com mais de $1,0 \mathrm{~cm}$ compr.

8. Folhas obovais $0,6-0,7 \mathrm{~cm}$ compr., $0,2-0,3 \mathrm{~cm}$ larg . . . 3. B. monnieri

8'. Folhas ovais a arredondadas, $1,0-2,0 \mathrm{~cm}$ compr., $0,8-1,0 \mathrm{~cm}$ larg . . .

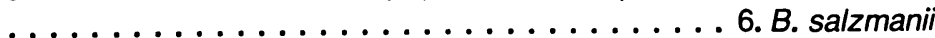

1'. Mais de duas flores por axila.

9. Folhas sésseis, base truncada, semiamplexicaule . . . . . . . 10. B. monnierioides

9'. Folhas pecioladas, base cuneada . . . . . . . 8. B. stricta

1. B. sessiliflora (Benth.) Edwall. Proc. Acad. Nat. Trans. Sc. Phil 98. p. 92. 1946. Herpestes sessiliflora Benth. Comp. Bot. Mag. 2. p. 58. 1836.

Figs. 36-38

Erva anual, rastejante, paludosa, $15-30 \mathrm{~cm}$ alt., glabra a subglabra. Folhas lanceoladas, sésseis, 2,0-3,0 cm compr., 0,5-0,8 cm larg., glabras, ápice obtuso, base atenuada, margem serreada na porção superior. Flores axilares, geminadas; sépalas externas ovais, internas filiformes; pétalas 4, alvas. Cápsula subglobosa.

Material examinado: São Lourenço da Mata; Tapera, B. Pickel 2804 (IPA); 2913 (IPA); 3630 (IPA).

Esta espécie é bastante semelhante pelo hábito, a Rotala ramosior (L.) Koehne Lythraceae, também de ambientes úmidos. Uma distinção prática imediata pode ser feita pelas folhas, pois em $B$. sessiliflora (Benth). Edwall, os bordos são serreados no terço apical, enquanto que em Rotala ramosior são lisos (Andrade-Lima \& Lima, 1968).

2. B. aquatica Aubl. Pl. Guian. 1. p. 128. 1775.

Figs. $39-40$

Erva ereta, paludosa, 5-15 cm alt., glabra. Folhas lanceoladas, sésseis, $3,0-5,0 \mathrm{~cm}$ compr., 0,5-1,5 cm larg., glabras, ápice agudo a obtuso, base atenuada subamplexicaule, margem serreada. Flores axilares, solitárias; sépalas externas oval-arredondadas, internas lanceoladas; pétalas 5, alvas; estames 5; pedicelo 0,3-0,5 cm compr. Cápsula ovóide.

Material examinado: Recife, P. Ferreira 71-64 (IPA). Olinda, B. Pickel 553 (IPA). Maranguape, Andrade-Lima 50-569 (IPA). Afrânio, Heringer et al. 291 (IPA).

3. B. monnieri (L.) Pennell Proc. Acad. Nat. Sc. Phil. 98. p. 92. 1946.

Lysimachia monnieri L. Cent. PI. 2. p. 9. 1756.

Herpestes monnieria H. B. K. Nov. Gen. Sp. 2. p. 336.1818.

Fig. 41.

Erva carnosa, reptante, paludosa, glabra. Folhas obovais, sésseis, 0,6-0,7 cm compr., 0,2-0,3 cm larg., glabras, ápice arredondado, base atenuada, margem inteira. Flores axilares, solitárias; sépalas externas lanceoladas, internas lineares; pétalas 5 , azuis; estames 4; pedicelo 1,0-1,5 cm compr. Cápsula ovóide.

Material examinado: Olinda; Casa Caiada, S. Tavares 610 (IPA). São João, AndradeLima 66-4715 (IPA).

Espécie halófila, ocorrendo em. locais alagados próximos ao oceano, ou no interior do continente, em lagoas salgadas temporárias. 
4. B. bacopoides (Benth.) Edwall. Proc. Acad. Nat. Trans. Sc. Phil. 98. p. 92.1946. Herpestes bacopoides Benth. in DC. Prodr. 10. p. 339. 1845.

Erva carnosa, pouco ramosa, $30-45 \mathrm{~cm}$ alt., glabra. Folhas linear-lanceoladas, sésseis, 2,5-3,5 cm compr., 0,5-1,0 cm larg., glabras, pontuadas, ápice obtuso, base atenuada subamplexicaule, margem serreada. Flores axilares, solitárias; sépalas externas ovais, internas lanceoladas; pétalas 5, azuis; estames 4; pedicelo 0,4-0,6 cm compr. Cápsula oblata.

Material examinado: Pernambuco, Gardner 1090 (K).

Esta espécie não foi coletada novamente no estado de Pernambuco.

5. B. depressa (Benth.) Edwall. Proc. Acad. Nat. Trans. Sc. Phil. 98. p. 92.1946. Herpestes depressa Benth. in DC. Prodr. 10. p. 395. 1845.

Erva decumbente, paludosa, 15-25 cm alt., glabra. Folhas linear-lanceoladas, sésseis, 1,3-3,0 cm compr., 0,1-0,3 cm larg., glabras, pontuadas, ápice agudo, base subamplexicaule, margem inteira. Flores axilares, solitárias; sépalas externas lanceoladas, internas linear-lanceoladas; pétalas 4-5, róseas com manchas amarelas; estames 4; pedicelo 0,2-0,4 cm compr. Cápsula ovóide.

Material examinado: Petrolina, G. Fotius 3468 (IPA). Floresta; Fazenda São José, Andrade-Lima, Z. Brito, C. Lima 13 (IPA). Parnamirim; Fazenda Travessia, F. Araújo 120 (IPA). Petrolina, Andrade-Lima 74-7653 (IPA).

6. B. salzmannii (Benth.) Edwall. Proc. Acad. Nat. Trans. Sc. Phil. 98. p. 95. 1946. Herpestes salzmannii Benth. Comp. Bot. Mag. 2. p. 58. 1836.

Fig. 42

Erva procumbente, paludosa, vilosa. Folhas ovais a arredondadas, sésseis, 1,0-2,0 $\mathrm{cm}$ compr., 0,8-1,0 cm larg., glabras na face superior, vilosas na face inferior, ápice arredondado, base amplexicaule, margem inteira. Flores axilares, solitárias; sépalas externas ovais, internas filiformes; pétalas 4, azuis; estames 4. Cápsula oblata.

Material examinado: Pombos, B. Pickel 2240 (IPA).

7. B. gratioloides (Cham.) Edwall Proc. Acad. Nat. Trans. Sc. Phil. 98. p. 92. 1946. Herpestes gratioloides Benth. Comp. Bot. Mag. 2. p. 57. 1836.

Erva perene, paludosa, $15-45 \mathrm{~cm}$ alt., glabra. Folhas lanceoladas, sésseis, $3,0-4,0 \mathrm{~cm}$ compr., 0,5-0,6 cm larg., glabras, pontuadas, ápice acuminado, base subamplexicaule, margem inteira ou serreada. Flores axilares, geminadas; sépalas externas lanceoladas, internas lineares; pétalas 4, azuis; estames 4; pedicelo ca. 0,1 cm compr. Cápsula oblata.

Material examinado: Jupi; margem da estrada Garanhuns-Lageado, Andrade-Lima 664721 (IPA). Ouricuri, Andrade-Lima et al. 109 (IPA).

8. B. stricta (Schrad.) Edwall. Proc. Acad. Nat. Trans. Sc. Phil. 98. p. 92. 1946. Herpestes stricta Schrad. Enum. Hort. Berol. 2. p. 142. 1822.

Fig. 43 
Erva subereta, paludosa, $30-80 \mathrm{~cm}$ alt., glabra. Folhas lanceoladas, $2,5-12,0 \mathrm{~cm}$ compr., 1,0-3,0 cm larg., subglabras, ápice agudo, base cuneada, margem crenàda a serreada; peciolo 0,3-1,0 cm compr. Fascículos axilares, com 5-8 flores; sépalas externas ovais, internas lanceoladas; pétalas 5, azuis; estames 4; pedicelo 0,1-0,4 cm compr. Cápsula globosa.

Material examinado: São Lourenço da Mata, B. Pickel 1207 (IPA); 2420 (IPA). Capoeiras, Andrade-Lima 71-6538 (IPA). Brejo da Madre de Deus, Andrade-Lima 73-7478 (IPA).

9. B. cyclophylla Fernald Rhodora 41. p. 446. 1939.

Figs. $44-45$

Erva prostrada, paludosa, glabra. Folhas ovais a arredondadas, sésseis, $0,6-0,8 \mathrm{~cm}$ compr., 0,4-0,6 cm larg., ápice arredondado, base subamplexicaule, margem inteira. Flores axilares, solitárias; sépalas externas subovais a ovais, internas lanceoladas; pétalas alvas; estames 4; pedicelo 0,3-0,4 cm compr. Cápsula ovóide.

Material examinado: Recife; Bonji, Parque do IPA, Giulietti 865-71 (IPA); Dois Irmãos, F. Galindo 116 (IPA).

Esta espécie era referida apenas para o Paraná (Barroso 1952). Em Pernambuco $B$. cyclophylla ocorre na zona da mata, em solos argilosos e encharcados, vivendo em associação com Lindernia microcalyx, L. crustacea, Micranthemum umbrosum e Callitriche deflexa - Callitrichaceae. Essa planta tem ciclo de vida de poucos dias (julho-agosto), aparecendo na época mais chuvosa.

10. Bacopa monnierioides (Cham.) Robinson Proc. Amer. Acad. Arts. 44. p. 614. 1909.

Figs. 46-49

Erva ereta, paludosa, $20-30 \mathrm{~cm}$ alt., glabra. Folhas lanceoladas, sésseis, $1,5-3,0$ compr., 0,6-1,0 cm larg., glabras, pontuadas, ápice obtuso, base subamplexicaule, margem crenada, em especial no ápice. Fascículos axilares, com 3-4 flores; sépalas externas ovais, internas filiformes; pétalas alvas, estames 4; pedicelo ca. 0,1 cm compr. Cápsula ovóide.

Material examinado: São Lourenço da Mata; Tapera, Engenho São Bento, B. Pickel 780 (IPA); 2803 (IPA); 3706 (IPA). Riachinho, Luetzelburg 1997 (IPA).

\section{Micranthemum Michx.}

1. M. umbrosum (Walt.) Blake Rhodora 17. p. 131. 1915.

Anonymus umbrosa Walt. Fl. Carol. p. 63. 1788.

Figs. 50-52

Figs. 50-52 - Micranthemum umbrosum (Walt.) Blake. 50 - Flor, 51 - Estame com apêndice glanduloso na base, 52 - Fruto. 53 - Torenia thouarsü (Cham. \& Schlecht.) Kuntze - Hábito. 54-56 - Lindernia. 54 - L. crustacea (L.) F.v.M. - Hábito. 55-56 - L. microcalyx Pennell \& Stehle. 55 - Hábito, 56 - Flor.

Figs. 50-52 - Micranthemum umbrosum (Walt.) Blake. 50 - Flower, 51 - Stamen with gladular appendages, 52 - Fruit. 53 - Torenia thouarsï (Cham. \& Schlecht.) Kuntze - Habit. 54-56 - Lindernia. 54 - L. crustacea (L.) F.v.M. - Habit. 55-56 - L. microcalyx Pennell \& Stehle. 55 - Habit, 56 - Flower. 


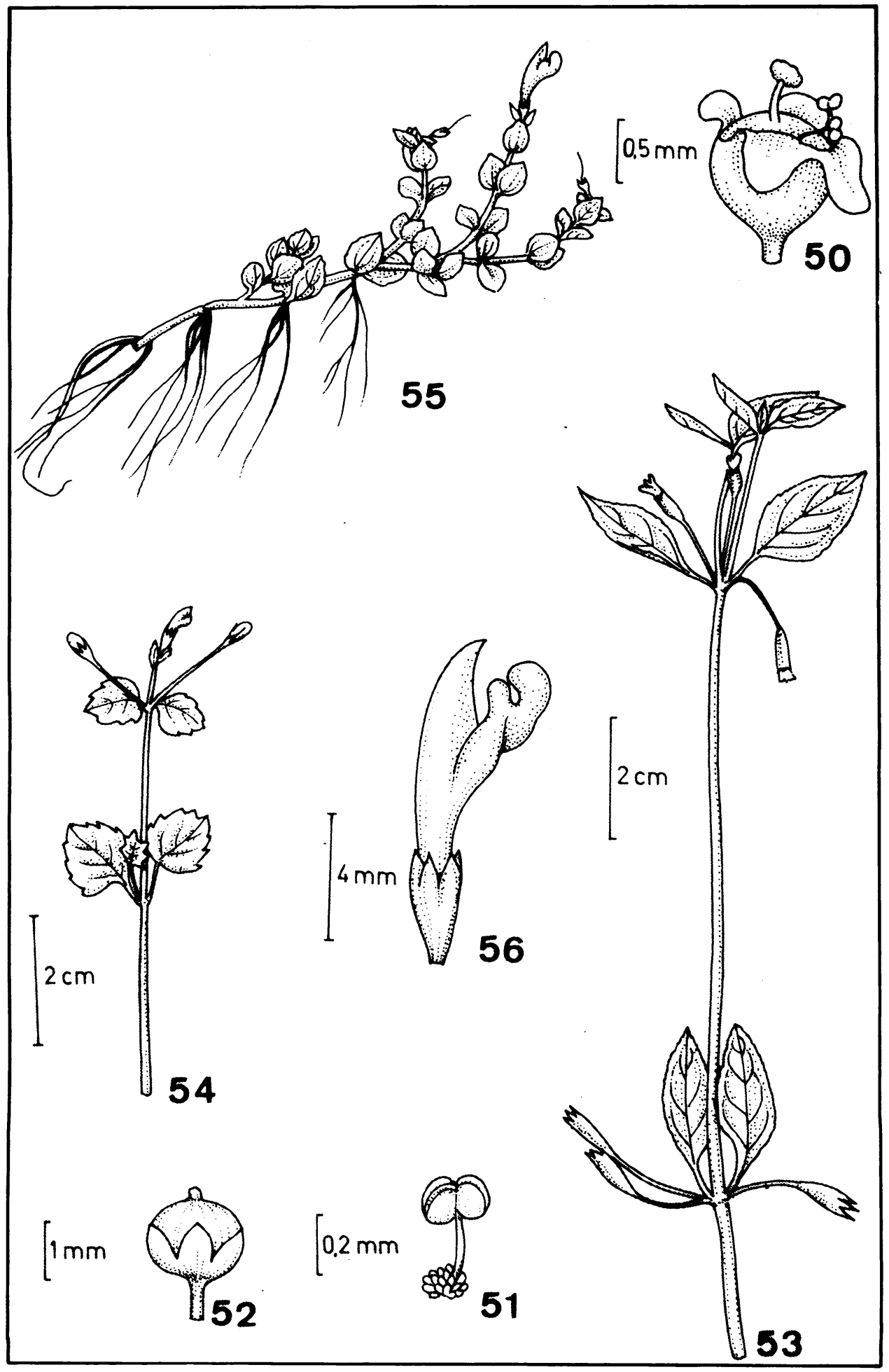


Erva rastejante. Folhas opostas, elíptico-orbiculares, sésseis, 0,5-0,6 cm compr., 0,3$0,5 \mathrm{~cm}$ larg., glabras, ápice e base arredondados, margem inteira. Flores axilares, subsésseis; cálice quase do mesmo tamanho da corola; corola alva ou amarelo-clara, bilabiada, lábio anterior curto, lábio posterior formado por 3 pétalas, sendo uma delas maior que as outras duas; estames 2, anteras largas, filetes duas vezes o tamanho das anteras, portando apêndice glanduloso na base, inseridos na fauce da corola; estigma captado. Cápsula globosa, 1,0-1,5 $\mathrm{mm}$ compr.

Material examinado: São Lourenço da Mata, B. Pickel 3372 (IPA). Serra Talhada, Heringer et al. 837 (IPA, RB).

Planta paludosa ou natante em riachos.

\section{Torenia L.}

1. T. thouarsii (Cham. et Schlecht.) Kuntze Rev. Gen. Plant. 2. p. 468. 1891.

Fig. 53

Erva de caule tetrangular, decumbente, $10-20 \mathrm{~cm}$ alt., glabrescente. Folhas opostas, ovais a oval-lanceoladas, 2,0-2,5 cm compr., 0,7-1,0 cm larg., subglabras, ápice agudo a obtuso, base arredondada decurrente no peciolo, margem crenado-serreada. Flores axilares, solitárias; sépalas unidas até quase o ápice, facilmente separáveis devido aos bordos muito tênues; corola rósea, bilabiada, lábio inferior bilobado, superior trilobado; estames 4, didinamos, filetes apendiculados; estilete alargando-se para o ápice, estigma bilamelado. Cápsula oblata, coberta totalmente pelo cálice.

Material examinado: Recife, Dois Irmãos, P. Ferreira 40-67 (IPA). Igarassu; Granja São Luis, Andrade-Lima 67-5150 (IPA).

Erva anual, ocorrendo em locais úmidos.

\section{Lindernia All.}

Ervas de folhas opostas; flores solitárias ou dispostas em racemos; cálice 5-partido ou tubuloso; corola bilabiada com lábio superior arredondado ou bilabiado e o inferior trilobado; estames 4, sendo 2 inseridos no tubo e 2 na fauce da corola, ou 2 estames e 2 estaminódios. Cápsula septicida com valvas indivisas; sementes reticuladas.

1. Pedicelo cilíndrico; flores com 2 estames e 2 estaminódios, filetes desprovidos de apêndices . . . . . . . . . . . . . . . . . . . . . 2. L. microcalyx

1'. Pedicelo anguloso; flores com 4 estames, sem estaminódios; 2 dos filetes com apêndices

2. Erva ereta; corola lilás . . . . . . . . . . . . . . . 1. L. crustacea

2'. Erva prostrada; corola alva ................... 3. L. diffusa

1. L. crustacea (L.) F. Muell. in DC. Prodr. 10. p. 413. 1845.

Fig. 54.

Erva ereta, 7-20 cm alt., subglabra. Folhas ovais, 1,0-1,3 cm compr., 0,8-1,2 cm larg., glabras, ápice obtuso, base truncada, margem denteada; peciolo 0,1-0,4 cm compr. Flores axilares, solitárias; cálice tubuloso, piloso nos ângulos; pétalas posteriores lilases, anterio- 
res amarelas; estames 4, sendo 2 com apêndices claviformes; pedicelo ereto, $0,7-1,4 \mathrm{~cm}$ compr., tetrangular. Cápsula subelipsóide, 0,3-0,4 cm compr.

Material examinado: Recife; Bonji, terrenos do IPA, V. Sobrinho s/n (IPA). Olinda; Casa Caiada, S. Tavares 610 (IPA). São Lourenço da Mata; Tapera, B. Pickel 3093 (IPA). Nazaré da Mata, J. C. Moraes s/n (EAN).

Planta anual, de terrenos úmidos, vivendo juntamente com pequenas Gramineas, Rubiáceas, Euforbiáceas e outras Escrofulariáceas, como por exemplo Lindernia microcalyx. Miranda (1977), apresenta um estudo morfológico e dos flavonóides das Lindernia da América do Sul e apesar de haver estudado as três espécies de Pernambuco, não faz citações das mesmas, para esse Estado.

2. L. microcalyx Pennell et Stehle Fl. Guadelupe et Depend. 2. p. 217. 1938.

Fig. 55-56

Erva ereta, $10-15 \mathrm{~cm}$ alt. Folhas ovais, sésseis, 0,5-0,8 cm compr., 0,4-0,6 cm larg., subglabras, ápice obtuso, base truncada, margem denteada. Flores axilares, solitárias; cálice 5-partido, glanduloso-piloso; pétalas alvas com manchas roxas; estames 2, inseridos na fauce da corola, estaminódios 2, claviformes; pedicelo ereto, $0,5-0,6 \mathrm{~cm}$ compr., cillndrico.

Material examinado: Recife; Bonji, terrenos do IPA, P. Ferreira 39 (IPA).

Habita locais semelhantes aos de Lindernia crustacea.

3. L. diffusa (L.) Wettst. Die Natürlichen Pflanzenfamilien 4. p. 36. 1895.

Erva prostrada, hispido-pilosa. Folhas ovais, 1,3-1,8 cm compr., 1,2-1,6 cm larg., subglabras ou pubescentes, ápice agudo a obtuso, base truncada, margem denteada; peciolo 0,1-0,3 cm. compr. Flores axilares, solitárias; cálice tubuloso, piloso nos ângulos; pétalas alvas; estames 4, sendo 2 com apêndices claviformes; pedicelo ereto, curto, anguloso. Cápsula oblata, 0,5-0,6 cm compr.

Material examinado: Recife; Areias, B. Pickel 3444 (IPA).

Esta espécie habita os solos arenosos do litoral do Estado de Pernambuco.

\section{Capraria L.}

1. C. biflora L. Sp. Pl. p. 628.1753.

- Nome vulgar: "erva-de-chã-de-calçada"

Erva perene, ereta, $40-50 \mathrm{~cm}$ alt., glabra a pubescente. Folhas alternas, lanceoladas, 2,0-5,5 cm compr., 0,8-1,8 cm larg., glabras a pubescentes, ápice agudo, base atenuada, margem denteada na porção superior. Flores axilares, geminadas; cálice 5-partido; corola campanulada; pétalas 5 , alvas; estames 4 , didínamos, maiores com anteras triangulares, menores com anteras elfipticas; pedicelo 0,4-0,6 cm compr. Cápsula ovóide.

Material examinado: São Lourenço da Mata, B. Pickel 441 (IPA). Ipojuca; Nossa Senhora do Ó, Sarmento s/n (IPA). Barreiros; São José da Coroa Grande, J. Falcão et al. 836 (IPA, RB). Itamaracá, F. Galindo 188 (IPA).

Espécie bastante freqüente tanto na orla marfítima, como na zona da mata do Estado. 


\section{Scoparia L.}

1. S. dulcis L. Sp. PI. p. 116. 1753.

Nome vulgar: "vassourinha-de-botão"

Erva anual, ereta, 30-50 cm alt., subglabra. Folhas opostas a verticiladas, obovais a oblanceoladas, 1,5-5,5 cm compr., 0,6-0,8 cm larg., glabras, ápice agudo, base atenuada, margem serreada na porção terminal. Flores axilares, solitárias; sépalas 4, livres; corola actinomorfa, pétalas 4, alvas, unidas apenas na base, pilosas; estames 4, pilosos na base, anteras com tecas paralelas; pedicelo $0,3-0,6 \mathrm{~cm}$ compr. Cápsula subglobosa, $0,3-0,4 \mathrm{~cm}$ compr., com cálice e estilete persistente.

Material examinado: Recife; Dois Irmãos, P. Miranda s/n (IPA); Curado, Andrade-Lima s/n (IPA); Curado, Andrade-Lima s/n (IPA); Bonji, V. Sobrinho s/n (IPA). Cabo, Andrade-Lima \& M. Costa 210 (IPA). São Lourenço da Mata; Engenho São Bento, B. Pickel 350 (IPA). Vitória de Santo Antão, S. Tavares 654 (IPA). Exu, Heinger et al. 1971 (IPA, RB, SPF). Serra Talhada, L. Queiroz 02 (IPA, SPF).

Esta é a espécie mais freqüente entre as Escrofulariáceas de Pernambuco, ocorrendo em todos os tipos de vegetação, desde o litoral até as caatingas. Sua área de distribuição abrange praticamente todo o Nordeste.

\section{Alectra Thunb.}

1. A. aspera (Cham. et Schlecht.) L. O. Williams Fieldiana Bot. 34. p. 118. 1972.

Glossostylis aspera Cham. et Schlecht. Linnaea 3. p. 22. 1828.

Melasma melampyroides (Rich.). Pennell ex. Britton et Wilson Sc. Surv. P. R. \& V. I. 6. p. 188. 1885.

Figs. 57-59

Erva anual, ereta, 30-60 cm alt., hispida. Folhas opostas, lanceoladas a oval-lanceoladas, sésseis, 3,0-4,5 cm compr., 1,0-1,5 cm larg., híspidas, ápice obtuso, base cuneada, margem irregularmente serreada. Flores axilares, sésséis ou curto pediceladas; cálice campanulado, sépalas 5, hispidas; corola amarela, quase do mesmo tamanho que o cálice; estames 4, didínamos, anteras arredondadas. Cápsula globosa, 0,7-1,0 cm compr.

Material examinado: Recife, A. Chiappeta et al. 343 (IPA); F. Galindo 112 (IPA); Curado, Andrade-Lima s/n (IPA). São Lourenço da Mata, B. Pickel 458 (IPA); 2464 (IPA). Caruaru, Andrade-Lima 71-6476 (IPA).

Planta escassa na zona da mata de Pernambuco, onde ocorre como invasora de culturas, em áreas úmidas.

Figs. 57-59 - Alectra aspera (Cham. \& Schlecht.) L.O. Williams. 57 - Cálice, 58 - Estame, 59 - Gineceu. 6061 -Agalinis hispidula (Mart.) Darcy. 60-Hábito, 61 - Estame. 62 - Buchnera longifolia H.B.K. - Pétala. 


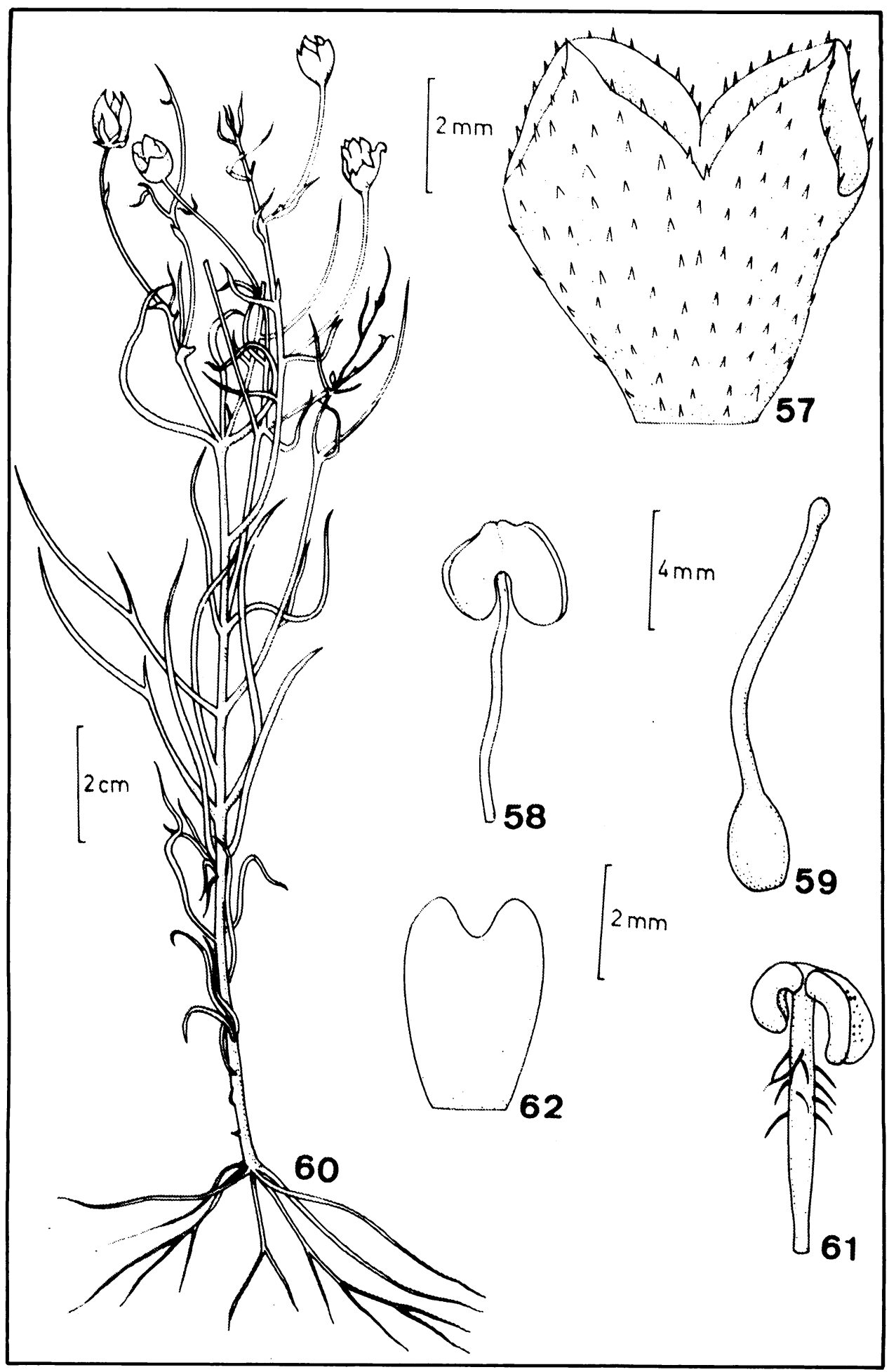




\section{Agalinis Raf.}

1. A. hispidula (Mart.) Darcy An. Miss. Bot. Gard. 6. p. 4. 1978. Gerardia hispidula Mart. FI. Bras. 7. p. 280. 1862.

Figs. $60-61$

Erva ereta, 20-60 cm alt. Folhas opostas, lanceoladas, 2,0-2,5 cm compr., 0,3-0,6 cm larg., ápice agudo, base cuneada, margem denteada, revoluta. Flores axilares, solitárias; cálice campanulado, sépalas 5, irregulares; corola roxo-clara; estames 4, didínamos, anteras divergentes. Cápsula ovóide, 0,8-1,0 cm compr.

Material examinado: São Lourenço da Mata; Tapera, B. Pickel 1110 (IPA); 2811 (IPA). També, M. Magalhães s/n (IPA); Andrade-Lima 52-1164 (IPA).

Em Pernambuco esta espécie ocorre em locais úmidos dos taboleiros arenosos e da zona da mata, onde aparece com porte e folhas maiores. Darcy (1978) revalidou o gênero Agalinis Raf., incluindo Gerardia L. na sinonímia.

\section{Buchnera L.}

Ervas eretas. Folhas opostas ou alternas. Flores dispostas em espigas terminais; cálice tubuloso, estriado, 5-denteado corola hipocraterimorfa; 4-5 lobada; estames 4, didinamos, anteras unitecas. Cápsula loculicida; sementes reticuladas.

1. Folhas de 2,5-11,0 cm compr., não adpressas ao caule.

2. Cálice 10-nérveo, sem nervuras intermediárias entre as nervuras principais; corola glabra externamente . . . . . . . . . . . . . . . . . 1. B. longifolia

2'. Cálice 10-nérveo, com nervuras intermediárias entre as nervuras principais; corola pubescente externamente ................... . . . rosea 1'. Folhas até $2,0 \mathrm{~cm}$ compr., adpressas ao caule . . . . . . . . . . 3. B. juncea

1. B. longifolia H. B. K. Nov. Gen. et Sp. 2. p. 340. 1818.

Fig. 62

Erva perene, ereta, $30-60 \mathrm{~cm}$ alt., híspida nas partes mais jovens. Folhas opostas a subopostas, eliptico-lanceoladas, sésseis, 5,0-11,0 cm compr., 0,6-1,0 cm larg., híspido-verrucosas, ciliadas, ápice agudo, margem inteira a irregularmente crenada. Espigas terminais; cálice 10-nérveo, sem nervuras intermediárias, glabro; corola azul, glabra externamente. Cápsula oblata.

Material examinado: São Lourenço da Mata; Tapera, B. Pickel 1109 (IPA).

2. B. rosea H. B. K. Nov. Gen. et Sp. 2. p. 342. 1818.

Erva perene, ereta, $40-50 \mathrm{~cm}$ alt., glabrescente. Folhas opostas a subopostas, lanceoladas, sésseis, $2,5-3,5 \mathrm{~cm}$ compr., $0,2-0,4 \mathrm{~cm}$ larg., glabras na face superior, hispidoescabras a subglabras na face inferior, ápice agudo, margem inteira a subserreada. Espigas terminais; cálice 10-nérveo, com nervuras intermediárias entre as nervuras principais, pubescente; corola roxo-clara, pubescente externamente. Cápsula ovóide. 
Material examinado: Goiana, Andrade-Lima 57-2703 (IPA); 58-2884 (IPA). Garanhuns; estrada para Palmeirina, Andrade-Lima 67-5087 (IPA).

3. B. juncea Cham. et Schlecht. Linnaea 2. p. 590. 1827.

Philcox (1965) refere Buchnera juncea Cham. et Schlecht. como ocorrendo no Estado de Pernambuco, além das espécies já citadas no presente trabalho.

\section{REFERÊNCIAS}

ANDRADE-LIMA, D. de 1954. Contribution to the study of the Flora of Pernambuco, Brazil Monografia I. Univ. Fed. Rural PE. 154p.

ANDRADE-LIMA, D. de 1966. Plantas "invasoras" da zona da mata de Pernambuco. Anais do XVI Cong. Nac. da Soc. Botânica do Brasil. Brasília. p. 299-367.

ANDRADE-LIMA, D. de \& GIULIETTI, A. M. 1972. Caryophylaceae de Pernambuco. Flora de Pernambuco I. Recife, p. 1-6.

ANDRADE-LIMA, D. de \& LIMA, A. M. B. 1968. Flora de Pernambuco - Angiospermae II. Anais do XIX Cong. Nac. da Soc. Botânica do Brasil. Fortaleza. p. 49-67.

BARRETO, R. C. 1985. Estudos taxonômicos sobre a famitia Lauraceae Lindley no Estado de PernambucoBrasil. Dissertação de mestrado, Univ. Federal Rural de Pernambuco, Recife, Pe.

BARROSO, G. M. 1952. Scrophulariaceae. Rodriguésia. 27: 9-64.

BARRINGER, K. 1983. Monopera a new genus of Scrophulariaceae from South America. Brittonia 35 (2): 111-114.

CRONQUIST, A. 1981. An integrated system of classification of flowering plants. Columbia University Press. New York. 1265 p.

D'ARCY, W. G. 1978. Names in Agalinis for some plants that were called Gerardia and Virgularia (Scrophulariaceae). Ann. Miss. Bot. Gard. 65(4): 769-771.

GIULIETTI, A. M. 1971. O gênero Phoradendron em Pernambuco. Anais do Instituto de Ciências Biologicas, UFRPe. Recife 1(1): 33-46.

GIULIETTI, A. M. 1972. Dizygostemon angustifolium nova espécie de Scrophulariaceae. Anais da Sociedade Botânica do Brasil - XXIII Congresso Nacional de Botânica, Garanhuns, p. 77.

GIULIETTI, A. M. \& SOUZA, V. C. 1990. Stemodia heterophylla nova espécie de Scrophulariaceae do Brasil. Bolm Botânica, Univ. S. Paulo 12:

GIULIETTI, A. M \& WANDERLEY, M. B. 1972. O gênero Dizygostemon - Scrophulariaceae. Anais da Sociedade Botânica do Brasil - XXIII Congresso Nacional de Botânica, Garanhuns, p. 79-81.

ICHASO, C. L. F. \& BARROSO, G. M. 1970. Scrophulariaceae. Flora Ilustrada Catarinense. Itajaí.

LIMA, R. B. 1985. Rhamnaceae de Pernambuco. Aspectos taxonômicos. Dissertação de Mestrado, Univ. Federal Rural de Pernambuco, Recife, Pe.

MELCHIOR, H. 1964. Tubiflorae In: Syllabus der Pflanzenfamilien. 12a. Gebrüder Borntraeger. Berlin.

MINOD, M. 1918. Contribution a l'étude du genre Stemodia et du grupe des Stémodiées de América. Bull. Soc. Bot. Genéve. Sér. 2: 10: 155-252.

MIRANDA, D. D. 1977. Flavonoid and morphological studies of Lindernia Allioni (Scrophulariaceae) in South America. Bot. J. Linn. Soc. (75): 47-67.

PENNELL, F. 1946. Reconsideration of the Bacopa-Herpestis problem of the Scrophulariaceae. Proc. Acad. Nat. Science Phil. 98: 83-98.

PHILCOX, D. 1965. Revision of the New World species of Buchnera L. (Scrophulariaceae). Kew Bull. 18: 275-316.

SCHMIDT, J. A. 1862. Scrophularinae. Flora Brasiliensis. In: C. F. Martius. (ed.) München 8(1): 230-339.

SOARES, C. M. C. 1979. Eriocaulaceae da zona da mata de Pernambuco. Dissertaçāo de Mestrado, Univ. Federal Rural de Pernambuco. Recife, Pe.

WETTSTEIN, R. 1895. Scrophulariaceae In: A. Engler \& K. Prant. (ed.) Die Natürlichen Pflanzenfamilien. 4(3): 39-107. 